\title{
Review Article \\ MicroRNAs in Kidney Transplantation: Living up to Their Expectations?
}

\author{
Eline K. van den Akker, Frank J. M. F. Dor, Jan N. M. IJzermans, and Ron W. F. de Bruin
}

Department of Surgery, Erasmus MC University Medical Center, P.O. Box 2040, 3000 CA Rotterdam, Netherlands

Correspondence should be addressed to Ron W. F. de Bruin; r.w.f.debruin@erasmusmc.nl

Received 18 December 2014; Revised 3 March 2015; Accepted 18 March 2015

Academic Editor: Kazuhiko Yamada

Copyright ( 2015 Eline K. van den Akker et al. This is an open access article distributed under the Creative Commons Attribution License, which permits unrestricted use, distribution, and reproduction in any medium, provided the original work is properly cited.

\begin{abstract}
Since the discovery of microRNAs, ample research has been conducted to elucidate their involvement in an array of (patho)physiological conditions. Ischemia reperfusion injury is a major problem in kidney transplantation and its mechanism is still not fully known, nor is there an effective therapy. Furthermore, no biomarker is available to specifically measure (ischemic) damage after kidney transplantation or predict transplantation outcome. In this review, we summarize studies conducted on microRNAs in renal ischemia reperfusion injury and kidney transplantation. Although the number of publications on miRNAs in different areas of nephrology is increasing every year, only a limited number of reports that address the role of miRNAs in relation to ischemia reperfusion injury or kidney transplantation are available. All reports up to June 2014 on microRNAs in renal IRI, kidney transplantation, and renal allograft status were included. Design of the studies was highly variable and there was limited overlap between microRNAs found in these reports. No single microRNA expression pattern could be found, although multiple microRNAs involved in the immune response seem to be altered after ischemia reperfusion injury and kidney transplantation. Although there is a growing interest in microRNA research in kidney transplantation aiming to identify biomarkers and therapeutical targets, to date, no specific microRNA has been demonstrated to be applicable as either one, mostly because of lack of specificity. More systematical research is needed to determine whether microRNAs can be applied as biomarker, therapeutic target, or therapeutic agent in kidney transplantation.
\end{abstract}

\section{Introduction}

Kidney transplantation (KT) is the treatment of choice for end stage renal failure. Ischemia reperfusion injury (IRI) is an inevitable consequence of KT. Ischemia leads to deprivation of nutrients and oxygen resulting in ATP depletion, loss of ion gradients, cell swelling, and increase of toxic by-products. Although contradictive, reperfusion enhances the damage by flow of oxygen rich blood, production of oxygen-free radicals, and activation of an inflammatory response [1]. After KT, IRI may induce delayed graft function (DGF), which is associated with increased comorbidity and longer hospital stay and is associated with acute and chronic rejection [2]. Despite extensive research, the specific mechanisms behind IRI are still not fully understood and no specific therapy is available. Preventing or treating IRI at an early stage could prevent DGF and thereby contribute to fast patient recovery, shortened hospital stay, and improved graft function.
MicroRNAs (miRNAs) are small, 19-25 nucleotide long, single-stranded RNA molecules which play an important role in posttranscriptional regulation of gene expression by inhibiting translation of target mRNAs. miRNAs are estimated to regulate approximately $60 \%$ of all transcripts. Let- 7 and lin- 4 were the first miRNAs discovered in Caenorhabditis elegans in 1993 by Lee and Ambros [3]. Five years later Fire and Mello reported on double-stranded RNA (dsRNA) that could silence genes through RNA interference (RNAi) [4]. Since then, miRNAs have been found in a wide variety of species from plants to viruses and up till now several hundred types are known in humans [3]. Other types of small noncoding RNAs have been found in plants and animals, like small-interfering RNAs and Piwi-interacting RNAs (piRNAs). In this review, we will focus mainly on miRNAs. Their small size and their stability and presence in body fluids make them promising candidates, both as therapeutical targets and as biomarkers. In the last years, 
much progress has been made in the understanding of the role of miRNAs in (patho)physiologic mechanisms. The goal of this review is to summarize the current knowledge of the role of miRNAs in transplant related IRI and kidney transplantation, with emphasis on their mechanistic role and use as biomarker and as either therapeutic target or agent.

\section{Methods}

We performed a PubMed-search containing the MeSHterms "microRNA" and "renal ischemia reperfusion injury." All abstracts were read and only those reports were selected when the main topic was microRNA-expression after renal ischemia reperfusion injury. We performed another search with "microRNA" and "kidney transplantation." Again only those reports were selected where the main topic was microRNA-expression and after kidney transplantation. Non-English papers were excluded. One report on microRNA and ischemia reperfusion injury was focused on a new method of analysis and was therefore excluded.

\section{1. miRNAs in the Kidney}

2.1.1. Tissue Specificity. As miRNAs play an important role in the regulation of protein synthesis, measurement of their expression may provide information about the physiology of organs in normal and diseased states. Since organs have a different spectrum of miRNA-expression, it was suggested that tissues contained specific miRNAs. However, in an expression atlas of human and mouse miRNAs, great similarity between the two species was found, and exclusive expression in an organ appeared to be very rare [5]. Most miRNAs were found in more than one organ. Expression of most miRNAs was ubiquitous, and some showed some degree of tissue specificity. miR-16 was found in all tissues and demonstrated to be the most abundant miRNA. miR-21 was also detected in most tissues, but abundance varied. Expression was higher in malignant cell lines. It was found that miRNAs that were previously considered as tissue specific were actually present in low concentrations in other tissue types as well [6]. Therefore, it was suggested to redefine tissue specific miRNAs as preferentially expressed or organ-enriched miRNAs.

Several organ-enriched miRNAs were found in the human kidney; miRNA-192, miRNA-194, miRNA-204, miRNA-215, and miRNA-216 were more abundant in kidney as compared to heart, lung, spleen, muscle, and prostate [7].

In the rat kidney, different expression profiles between the cortex and medulla have been described [8]. miRNA-192 and miRNA-194 were significantly more abundant in the cortex. Eleven miRNAs were found with a higher expression in the medulla, among them miR-30c and miR-200c.

2.1.2. miRNAs in Ischemia Reperfusion Injury and Kidney Transplantation. Studies on miRNAs in renal IRI and KT have mainly focused on finding an early and specific biomarker for graft function. Serum creatinine is now used to monitor the function of the graft but is a late biomarker with low specificity and sensitivity. Seven studies have used human kidney biopsies to study miRNA expression in normal grafts compared to those with acute rejection or interstitial fibrosis and tubular atrophy (IF/TA) [9-14]. One study focused on expression differences between operationally tolerant patients and patients with stable graft function under immunosuppression [15]. In five studies, animal experiments were used to investigate the involvement of miRNAs in renal IRI [16-20]. An overview is given in Table 1. Most studies first perform genome-wide expression profiling using kidney tissue, either after renal IRI in animals or from clinical biopsies or urine samples. To verify expression levels of a miRNA of interest, qRT-PCR is used. To further investigate their function, the majority of the reports use kidney cell lines such as HK-2, HRC, or PTEC, or PBMCs.

2.2. In Vivo Studies. Dicer is an enzyme found in the cytosol and cleaves precursor miRNA to produce mature miRNAs [21]. Deletion of Dicer is used to study the role of miRNAs in different organ systems. Mice with targeted deletion of Dicer in renal proximal tubule develop normally with no abnormalities in the kidney [16]. Under normal conditions $80 \%$ of 173 measured miRNAs in these mice had a significantly lower expression in the kidney compared to wild type controls. After bilateral renal ischemia for 30 minutes, these mice were protected against IRI. Survival was significantly higher in the Dicer-knockout group, and damage to the proximal tubule decreased. miRNA-profiling in kidney after 12 and 48 hours of reperfusion showed several up- and downregulated miRNAs in the cortex (with a $\log 2$ fold change $>2$ ) (Table 1). Of the 13 upregulated miRNAs, only two (miR-132, miR-362) were both upregulated after 12 and after 48 hours. In the downregulated miRNAs only one (miR379) was found at both time points. Both upregulated miR-132 and downregulated miR-379 are thought to play a role in the MAPK-pathway, which is known to be involved in renal IRI $[22,23]$.

To study the effect of lymphocyte infiltration on miRNA expression, $\mathrm{R}^{\circ} / \mathrm{c} \gamma^{\circ}$ mice that lack NK cells, NKT cells, B cells, and $\mathrm{T}$ cells were subjected to 30 minutes of renal IRI, and miRNA expression was compared to wild type mice [17]. Differential expression of miR-21, miR-20a, miR-146a, miR-199a3p, miR-214, miR-192, miR-187, miR-805, and miR-194 in the kidney of both groups was found. The miRNA expression pattern over a time course after IRI was similar between wild type and $\mathrm{R}^{\circ} / \mathrm{c} \gamma^{\circ}$ mice, suggesting that the miRNA profile after IRI seems to be independent of infiltrating lymphocytes.

When IRI was compared to sham-operated mice, 5 differentially expressed miRNAs were identified in the kidney [24]. Three of them, miR-17-5, miR-21, and miR-106, had fold changes of more than $30 \%$ at 24 hours after reperfusion. miR17-5 and miR-106 belong to the same miR-17 family and had similar expression patterns. In a time course, it was seen that miR-17-5 was upregulated from 24 hours until 3 days after reperfusion. miR-21 was upregulated at 3 and 4 days after reperfusion. At all measured time points (1, 3, and 4 days after reperfusion), a significant correlation was found between miR-17-5 and miR-21. The time points at which these miRNAs were upregulated may give some insight in 
TABLE 1: Up- and downregulated miRNAs found in in vivo studies. miRNA-: downregulated miRNA, miRNA+: upregulated miRNA, MV: microvesicles, EPC: endothelial progenitor cells, and AmiR = antagomir.

\begin{tabular}{|c|c|c|c|c|c|c|c|}
\hline Author & Species & Focus & Control & Tissue & Time point & MicroRNA- & MicroRNA+ \\
\hline $\begin{array}{l}\text { Wei et al. } \\
{[16]} \\
2010\end{array}$ & Mice & $\begin{array}{l}\text { Dicer }-/- \text { in } \\
\text { proximal } \\
\text { tubules } \\
30 \text { min renal } \\
\text { IRI }\end{array}$ & Wild type & Cortex & $12 \mathrm{~h}$ & $\begin{array}{c}\text { miR-18 } \\
\text { miR-127 } \\
\text { miR-135b } \\
\text { miR-296 } \\
\text { miR-322 } \\
\text { miR-379 } \\
\text { miR-487b } \\
\text { miR-491 } \\
\\
\text { miR-324-3p } \\
\text { miR-379 } \\
\text { miR-455-3p }\end{array}$ & $\begin{array}{c}\text { miR-17-3p } \\
\text { miR-132 } \\
\text { miR-207 } \\
\text { miR-362 } \\
\text { miR-489 } \\
\text { miR-685 } \\
\text { miR-687 } \\
\text { miR-7 } \\
\text { miR-132 } \\
\text { miR-362 } \\
\text { miR-467 } \\
\text { miR-486 } \\
\text { miR-495 } \\
\text { miR-668 } \\
\text { miR-694 }\end{array}$ \\
\hline $\begin{array}{l}\text { Godwin et al. } \\
{[17]} \\
2010\end{array}$ & Mice & $\begin{array}{l}30 \text { min renal } \\
\text { IRI }\end{array}$ & Sham & Kidney & $\begin{array}{c}\text { 1-3-5-7-14- } \\
21-30 \\
\text { days }\end{array}$ & $\begin{array}{l}\text { miR-187 } \\
\text { miR-192 } \\
\text { miR-194 } \\
\text { miR-805 }\end{array}$ & $\begin{array}{c}\text { miR-20a } \\
\text { miR-21 } \\
\text { miR-146a } \\
\text { miR-199a-3p } \\
\text { miR-214 } \\
\end{array}$ \\
\hline $\begin{array}{l}\text { Xu et al. [19], } \\
2012\end{array}$ & Mice & $\begin{array}{l}15 \text { min pre- } \\
\text { conditioning } \\
\text { before } 30 \mathrm{~min} \\
\text { renal IRI }\end{array}$ & IRI/IRI + anti-miR-21 & Kidney & $\begin{array}{c}4 \mathrm{~h} \\
24 \mathrm{~h} \\
4 \text { days }\end{array}$ & & miR-21 \\
\hline $\begin{array}{l}\text { Jia et al. [28], } \\
2013\end{array}$ & Mice & $\begin{array}{l}\text { Xenon pre- } \\
\text { conditioning } \\
\text { before } 30 \mathrm{~min} \\
\text { renal IRI }\end{array}$ & IRI/IRI + anti-miR-21 & Kidney & $24 \mathrm{~h}$ & & miR-21 \\
\hline $\begin{array}{l}\text { Kaucsár et al. } \\
{[24]} \\
2013\end{array}$ & Mice & $\begin{array}{l}20 \text { and } \\
30 \mathrm{~min} \text { IRI }\end{array}$ & Sham & Kidney & $\begin{array}{c}24 \mathrm{~h} \\
3 \text { days } \\
4 \text { days }\end{array}$ & & $\begin{array}{c}\text { miR-17-5 } \\
\text { miR-21 } \\
\text { miR-106 }\end{array}$ \\
\hline $\begin{array}{l}\text { Saikumar } \\
\text { et al. [18], } \\
2012\end{array}$ & Rat & $\begin{array}{l}30 \text { min renal } \\
\text { IRI }\end{array}$ & Sham & $\begin{array}{l}\text { Kidney } \\
\text { cortex }\end{array}$ & $24 \mathrm{~h}$ & & $\begin{array}{c}\text { miR-21 } \\
\text { miR-155 } \\
\text { miR-18a }\end{array}$ \\
\hline $\begin{array}{l}\text { Cantaluppi } \\
\text { et al. [20], } \\
2012\end{array}$ & Rat & $\begin{array}{l}\text { MV EPC + } \\
45 \text { min renal } \\
\text { IRI }\end{array}$ & $\begin{array}{l}\text { Sham } \\
\text { IRI } \\
\text { IRI MV EPC } \\
\text { (+RNAse/siRNA/AmiR126/296) } \\
\text { IRI MV fibroblast }\end{array}$ & Kidney & $\begin{array}{c}2 \text { days } \\
7 \text { days } \\
180 \text { days }\end{array}$ & & $\begin{array}{l}\text { miR-126 } \\
\text { miR-296 }\end{array}$ \\
\hline
\end{tabular}

which mechanism they are involved, either the injury and maintenance phase (miR-17-5) or recovery phase (miR-21). Their correlation suggests that these miRNAs influence each other's expression.

To study miRNA profiles after renal IRI in rats, renal pedicles were clamped for 30 minutes and miRNA expression in kidney, blood, and urine was compared to sham-operated rats at 24, 72, and 120 hours after reperfusion [18]. A $>2$-fold difference in expression was considered significant. Among the miRNAs which were differentially expressed at all three time points, three miRNAs of interest were further investigated: miR-18a, miR-21, and miR-155. Expression data were validated using qRT-PCR and compared between time points but also between cortex and medulla. miR-21 expression in the cortex increased after reperfusion and remained stable during the time course. In the medulla however expression continued to rise from a fold change of $\sim 2.5$ at 24 hours to a fold change of $\sim 13$ at 120 hours. miR-155 had a high expression ( $\sim 6$-fold change) at 24 hours in the cortex, which decreased to a fold change of $\sim 3$ at 120 hours. In the medulla, expression showed a reversed course, with low expression at 24 hours and a fold change of $\sim 5$ at 120 hours.

The course of miR-18a did not differ between cortex and medulla. Furthermore, expression of these miRNAs did not change in other tissues (heart, liver, lung, and spleen) after renal IRI. Expression in whole blood showed a significant decrease of the three miRNAs after reperfusion. In urine, only miR-21 showed a significant increase at 72 hours. miR-18a was not detectable in urine. Using Target Scan, 29 mRNA targets involved in apoptosis and cell proliferation were found for 
the three miRNAs, but their precise role was not investigated any further.

Ischemic Preconditioning (IPC) has been shown in some models to be an efficient technique to ameliorate damage by IRI in different organs like heart, brain, liver, and kidney [25-27]. The possible involvement of miR-21 in its protection against IRI was studied in a rat model [19]. miR-21 was chosen because of its proapoptotic targets. miR-21 expression was significantly higher after IPC and IRI compared to sham treatment. This corresponded with lower serum creatinine levels at 24 hours after IRI. When anti-miR-21 was administered before IPC, no rise in miR-21 was seen, and protection by IPC was abolished. When anti-miR-21 was administered before IRI without IPC, no effect on the severity of IRI was seen. This suggests that miR-21 is involved in induction of the protective effect of IPC and that administration of miR-21 before IRI may mimic the effects of IPC. These authors also showed that preconditioning with xenon provides similar effects on miR21 expression as IPC [28]. Pretreatment with xenon, a noble gas with volatile anaesthetic properties, resulted in protection against IRI. Again, this effect was dependent on miR-21 and protection was lost when anti-miR-21 was administered.

Microvesicles derived from endothelial progenitor cells have the ability to induce resistance against renal IRI [20]. This was not seen after administering microvesicles from fibroblasts. When treated with endothelial microvesicles, creatinine and BUN levels were significantly lower compared to untreated controls. Via microarray analysis, 26 miRNAs were found to be expressed in these microvesicles. miR-126 and miR-296 were chosen for further analysis because of their proangiogenic and antiapoptotic effects. Using qRT-PCR, it was found that miR-126 and miR-296 were expressed in endothelial progenitor microvesicles, but not in microvesicles derived from fibroblasts. When anti-miR-126 and anti-miR296 were added to the microvesicles, the protective effect was lost, showing that the protective effect was dependent on miR-126 and miR-296.

Because the aims, models, methods, and time points used in these studies differ considerably, it is difficult to draw an overall conclusion on the role and relevance of specific miRNAs in IRI. miRNA expression associated with protection against IRI cannot be compared to the profiled miRNAs associated with IRI itself. In the former the emphasis is to find protective miRNAs, while in the latter the pathophysiological response of miRNAs after IRI is measured.

Another reason for the lack in overlap between miRNAs is that initial profiling experiments later randomly select particular miRNAs of interest and neglect the role of other miRNAs found in these experiments. Dicer- $/$ - mice which are protected against renal IRI have a low expression of miR194. Godwin et al. [17] found a downregulation of miR-194 after renal IRI, which suggests that low expression of miR-194 is involved in protection against IRI (Table 1).

2.3. Clinical Studies. Already in 2007 , a miRNA profile in patients with acute rejection was reported [9]. Cortical biopsies from three kidneys with acute rejection after live donor KT were compared to 3 biopsies retrieved from kidney tissue after nephrectomy because of a renal tumour. Biopsies were taken on clinical indication. Results showed 8 upregulated and 12 downregulated miRNAs, with a ratio (rejection/normal) $<0.5$ or $>2.0$ considered significant (Table 1 ). Another profiling study compared miRNA expression in biopsies suffering from DGF, acute rejection, or antibodymediated rejection (AMR) with normal allograft biopsies [14]. In the DGF group, all upregulated miRNAs (Table 1) are involved in cell death and proliferation. Only one miRNA was also upregulated in AMR, miR-182, which was found to be upregulated in a murine IRI model as well [16]. miR182 inhibits FOXO1, which in turn causes proliferation of Thelper cells and is associated with cardiac allograft rejection in mice and ischemic damage in the brain $[16,29,30]$. Furthermore, an overlap of six miRNAs was found (miR155, miR-125a, miR-30c, miR-27b, miR-193b, and miR-125b) in the acute rejection set of another study, in which biopsies of 17 normal allografts were compared with 12 allografts with acute rejection [10]. In this study, miR-142-5p, miR-155, and miR-223 were the most significantly upregulated miRNAs in acutely rejected kidneys $(P<0.0001)$. A positive correlation between the expression of the T-cell marker CD3 and miR$142-5 p$ was found. Since miR-142-5p is mostly expressed in hematopoietic cells, its presence can be attributed to the influx of inflammatory cells in the kidney [31]. In PBMCs, expression levels of miR-142-5p may vary and are significantly increased in chronic antibody-mediated rejection compared to stable graft function but are not altered during acute rejection [32]. This suggests that miRNA-142-5p in PBMC may be a marker for antibody-mediated chronic rejection.

Since biopsies are invasive and bear a high risk for complications, a noninvasive method to measure rejection is preferred. miRNAs can be measured in the urine, which could be a promising way to find biomarkers for acute rejection. As mentioned before, miR- 21 and miR- 155 can be found in rat urine samples. In the same study, urine samples of 22 patients with acute kidney injury admitted to the ICU with high serum creatinine levels and elevated levels of KIM1 in the urine were collected and miRNA expression was compared to urine samples of 25 healthy volunteers [18]. Among the 22 ICU-patients, 9 were KT-recipients, and 13 had acute kidney injury of their native kidneys. In the patients with AKI (both native and transplant kidneys) an increased expression of miR-21 and decreased expression of miR-155 were found compared to healthy individuals.

Lorenzen et al. compared 68 urine samples of 62 patients with biopsy proven acute rejection with 20 samples of 19 patients with stable graft function [11]. As a disease control group, 13 urine samples of stable transplant recipients with a urinary tract infection were included. Twenty-one miRNAs were found with a $>10$-fold difference in expression between patients with acute rejection and stable controls. An increase of miR-10a and a decrease of miR-10b and miR-210 were found in urinary samples from patients with acute rejection. miR-210 correlated with glomerular filtration rate over time and a normalization of miR-210 levels was seen after successful antirejection therapy. Compared to the expression values in urinary samples with urinary tract infection only miR-210 showed a differential expression, suggesting miR-210 could 
act as a urinary biomarker and predictor for acute rejection and long term graft function, respectively.

A similar study was done to find a urinary biomarker for IF/TA [13]. Thirteen biopsies with chronic allograft dysfunction and IF/TA were compared to 5 normal biopsies, all from recipients of a kidney from a deceased donor. 56 differentially expressed miRNAs were found. With use of a target prediction program, fold change, and statistical significance they focused on 5 miRNAs (miR-142-3p, miR204, miR-107, miR-211, and miR-32) for further research. In urinary samples, a significant difference was found for three of the five miRNAs, namely, miR-142-3p, miR-204, and miR211. Although the predictive value still has to be established, this miRNA signature is a possible biomarker for IF/TA. With an in silico model, targets of these miRNAs were predicted and were found to be the costimulatory molecule CD28 on T-helper cells, B-cell development, and allograft rejection signalling. Other biological functions regulated by this miRNA signature are apoptosis, lymphocyte proliferation, and differentiation of natural killer (NK-) cells, B-cells, and T-cells. Furthermore, a decrease in miR-204 is associated with increased apoptosis in HeLa cells [33]. Using sequencing to profile miRNA expression, biopsies with IF/TA and 4 normal biopsies were compared [12]. In biopsies with IF/TA a differential expression (>2-fold) of several miRNAs (Table 1) was found, including miR-223 which was increased and the miR-30 family, which was decreased. Another study compared IF/TA urine samples to stable graft urine samples. They found 22 differentially expressed miRNAs $(P<0.01$ with a false discovery rate $<15 \%$ ) (Table 1 ). Differential expression of miR-99a, miR-140-3p, miR-200b, and miR-200* was seen both early and late after transplantation (3.73 \pm 1.30 and $20 \pm 4$ months, resp.) [34].

The limited number of human studies that has been conducted so far has yielded hardly any overlap in miRNAs. Comparison of these studies is limited by the use of different patient populations and tissues, like biopsies from cortex, percutaneous core needle biopsies, or urine. Other limitations are the different time points when samples were collected, even within one study. In addition, the focus of the studies differed between acute rejection and IF/TA in which involvement of miRNA undoubtedly differs.

A few miRNAs are found in multiple reports. miR-142$3 p$ is upregulated in both reports on acute rejection [10] and IF/TA $[12,13]$. miR-142-3p is mostly found in hematopoietic cells [5] and is associated with upregulation of CD25+ CD4 T-cells [35] and downregulation of heat shock protein (HSP)70 [36]. Another overlapping miRNA, miR-223, is also associated with inflammation, regarded as modulator of neutrophil maturation and fine tuner of granulocyte function [37] and is also found in monocytes [31].

Low expression of the miR-30 family was reported in two experiments. The miR-30 family is shown to be needed in kidney development [38] and miR-30 suppresses apoptosis by targeting the mitochondrial fission machinery [39] (Table 2).

2.4. In Vitro Studies. In mice, $\mathrm{miR}-21$ was found to play a role in renal IRI [17]. Since miR-21 is associated with cell death, proliferation, and fibrosis [40-42], the role of miR-21 in proliferation and renal fibrosis was studied using primary cultures from murine tubular epithelial cells. Knockdown of miR-21 led to increased cell death, whereas overexpression resulted in decreased cell death. Overexpression of miR21 did not prevent cell death in cells undergoing ischemia, however.

HIF- $1 \alpha$ is protective against IRI as it promotes alterations in expression of genes involved in tissue repair after ischemia. miRNA-127 was found to be involved in the HIF- $1 \alpha$ pathway, and IRI in NRK52E rat kidney cells and HK-2 cells stabilized HIF- $1 \alpha$ expression, which upregulated miR-127. Following renal ischemia and reperfusion in rats, an increased expression of rno-miR-127 was found, and Kinesin Family Member 3B (KIF3B), which is involved in cellular endocytosis, was identified as a novel target of miR-127 [43].

In human PBMCs from recipients with stable graft function under immunosuppression, expression of miR-106b, miR-142-3p, miR-450b-5p, and miR-876-3p was significantly lower and miR-98, miR-148b, miR-324-5p, and miR-508$3 p$ were significantly higher expressed, compared to operationally tolerant recipients [15].

When PBMCs of healthy volunteers were stimulated with phytohemagglutinin A (PHA) and IL-2, expression of miR142-3p, miR-324-5p, and miR-450b-5p decreased and expression of miR-876-3p increased. Further investigation showed higher expression of miR-142-3p in B-cells in operationally tolerant patients.

PHA stimulation of PBMCs was also performed to study the presence of miRNAs found earlier in human kidney biopsies [10]. Of the 7 upregulated miRNAs in the kidney, only miR-155 was increased in stimulated PBMCs, whereas let-7c was decreased. miR-223 and miR-142-5p, however, were decreased in PBMCs in contrast to their upregulation in kidney tissue.

In HK-2 cells, it was found that IRI causes a significant downregulation of miR-205. IRI was induced by culturing cells in low oxygen $(0.1 \%)$ for 16 hours, followed by 3 or 10 hours of reoxygenation [44]. Lower expression of miR205 was associated with a decreased cell survival. In cells overexpressing miR-205, there was a significant better cell survival after IRI. This protection was associated with the suppression of EGLN2 and an increase of HIF-1 $\alpha$ and HO1 .

One in vitro model focused on IF/TA induced by hypoxia in renal epithelial cells. The authors found downregulation of miR-124 after 48 hours of hypoxia. miR-124 seems to regulate MMP-2, a fibrosis associated gene, and overexpression of miR-124 reversed increased proliferation after hypoxia, although this was independent of MMP-2 [45] (Table 3).

Well-recognized limitations of these in vitro studies are that the pathology of IRI is difficult to capture in vitro, [19] that mostly only one cell line is studied and the focus is on the role of one particular miRNA found previously in literature or previous investigation.

\section{Discussion}

Despite the great interest in miRNAs in biomedical research, there are only few experimental and clinical studies on 
TABLE 2: Overview of experiments using human (kidney) tissue. LTx = liver transplantation. IF/TA = interstitial fibrosis and tubular atrophy. $\mathrm{STA}=$ soluble transplant antigen. $\mathrm{AMR}=$ antibody-mediated rejection. DGF = delayed graft function.

\begin{tabular}{|c|c|c|c|c|c|c|c|}
\hline Author & Group & Focus & Control & Tissue & $\begin{array}{l}\text { Time point after } \\
\text { transplantation }\end{array}$ & MicroRNA- & MicroRNA+ \\
\hline $\begin{array}{l}\text { Sui et al. [9], } \\
2008\end{array}$ & $\begin{array}{l}\text { Human live } \\
\text { kidney } \\
\text { donors }\end{array}$ & $\begin{array}{l}\text { Acute } \\
\text { rejection }\end{array}$ & $\begin{array}{c}\text { Tumor } \\
\text { nephrectomy }\end{array}$ & Cortex & $\begin{array}{l}\text { Histologically } \\
\text { confirmed acute } \\
\text { rejection }\end{array}$ & $\begin{array}{c}\text { miR-17-3p MM1 } \\
\text { miR-197 MM2 } \\
\text { miR-326 } \\
\text { miR-330 MM1 } \\
\text { miR-346 } \\
\text { miR-483 } \\
\text { miR-516 } \\
\text { miR-524* } \\
\text { miR-611 } \\
\text { miR-654 } \\
\text { miR-663 }\end{array}$ & $\begin{array}{c}\text { miR-125a MM1 } \\
\text { miR-125a } \\
\text { miR-320 } \\
\text { miR-381 } \\
\text { miR-602 } \\
\text { miR-628 } \\
\text { miR-629 } \\
\text { miR-658 }\end{array}$ \\
\hline $\begin{array}{l}\text { Anglicheau et al. } \\
{[10], 2009}\end{array}$ & $\begin{array}{l}\text { Human living } \\
+ \text { deceased } \\
\text { donors }\end{array}$ & $\begin{array}{l}\text { Acute } \\
\text { rejection }\end{array}$ & $\begin{array}{l}\text { Normal } \\
\text { allograft }\end{array}$ & Biopsy & Variable & $\begin{array}{c}\text { Let-7c } \\
\text { miR-10a } \\
\text { miR-10b } \\
\text { miR-30a } \\
\text { miR-30b } \\
\text { miR-30c } \\
\text { miR-30e-3p } \\
\text { miR-32 } \\
\text { miR-125a } \\
\text { miR-200a }\end{array}$ & $\begin{array}{c}\text { miR-142-3p } \\
\text { miR-142-5p } \\
\text { miR-146a } \\
\text { miR-146b } \\
\text { miR-155 } \\
\text { miR-223 } \\
\text { miR-342 }\end{array}$ \\
\hline $\begin{array}{l}\text { Lorenzen et al. [11], } \\
2011\end{array}$ & $\begin{array}{l}\text { Human living } \\
+ \text { deceased } \\
\text { donors }\end{array}$ & $\begin{array}{l}\text { Acute } \\
\text { rejection }\end{array}$ & $\begin{array}{c}\text { Normal allo- } \\
\text { graft/urinary } \\
\text { tract } \\
\text { infection }\end{array}$ & Biopsy, urine & $\begin{array}{l}6 \text { weeks } \\
3 \text { months } \\
6 \text { months }\end{array}$ & $\begin{array}{l}\text { miR-10b } \\
\text { miR-210 }\end{array}$ & miR-10a \\
\hline $\begin{array}{l}\text { Scian et al. [13], } \\
2011\end{array}$ & $\begin{array}{l}\text { Human } \\
\text { deceased } \\
\text { donors }\end{array}$ & IF/TA & $\begin{array}{l}\text { Normal } \\
\text { allograft }\end{array}$ & Biopsy, urine & $>9$ months & $\begin{array}{c}\text { miR-107 } \\
\text { miR-204 } \\
\text { miR-211 }\end{array}$ & $\begin{array}{c}\operatorname{miR}-32 \\
\text { miR-142-3p }\end{array}$ \\
\hline $\begin{array}{l}\text { Ben-Dov et al. [12], } \\
2012\end{array}$ & $\begin{array}{l}\text { Human living } \\
\text { + deceased } \\
\text { donors }\end{array}$ & IF/TA & $\begin{array}{l}\text { Normal } \\
\text { allograft }\end{array}$ & Biopsy, urine & Variable & miR-30 family & $\begin{array}{c}\text { miR-21 } \\
\text { miR-21* } \\
\text { miR-142-3p } \\
\text { miR-223 } \\
\text { miR-506 } \\
\text { miR-508 } \\
\text { miR-509-3p } \\
\text { miR-509-5p } \\
\text { miR-514a }\end{array}$ \\
\hline $\begin{array}{l}\text { Danger et al. [15], } \\
2012\end{array}$ & $\begin{array}{l}\text { Human living } \\
+ \text { deceased } \\
\text { donors }\end{array}$ & STA & $\begin{array}{c}\text { Operationally } \\
\text { toler- } \\
\text { ant/healthy } \\
\text { volun- } \\
\text { teers/LTx } \\
\text { recipient }\end{array}$ & PBMCs & Variable & $\begin{array}{c}\text { miR-106b } \\
\text { miR-142-3p } \\
\text { miR-450b-3p } \\
\text { miR-876-3p }\end{array}$ & $\begin{array}{c}\text { miR-98 } \\
\text { miR-148b } \\
\text { miR-324-5p } \\
\text { miR-508-3p }\end{array}$ \\
\hline $\begin{array}{l}\text { Danger et al. [32], } \\
2013\end{array}$ & $\begin{array}{l}\text { Human } \\
\text { PBMC }\end{array}$ & $\begin{array}{l}\text { Chronic } \\
\text { AMR }\end{array}$ & $\begin{array}{l}\text { Acute rejec- } \\
\text { tion/healthy } \\
\text { volun- } \\
\text { teers/renal } \\
\text { failure }\end{array}$ & PBMCs & Variable & & miR-142-5p \\
\hline
\end{tabular}


TABLE 2: Continued.

\begin{tabular}{|c|c|c|c|c|c|c|c|}
\hline Author & Group & Focus & Control & Tissue & $\begin{array}{l}\text { Time point after } \\
\text { transplantation }\end{array}$ & MicroRNA- & MicroRNA+ \\
\hline \multirow{3}{*}{$\begin{array}{l}\text { Wilflingseder et al. } \\
{[14], 2013}\end{array}$} & \multirow{3}{*}{$\begin{array}{l}\text { Human living } \\
\text { + decreased } \\
\text { donors }\end{array}$} & AMR & & \multirow{3}{*}{ Biopsy } & \multirow{3}{*}{ Variable } & \multirow{3}{*}{$\begin{array}{c}\text { Let-7b } \\
\text { miR-23b } \\
\text { miR-27b } \\
\text { miR-30c-2* } \\
\text { miR-99b } \\
\text { miR-99b } \\
\text { miR-125a } \\
\text { miR-125b-2 } \\
\text { miR-138 } \\
\text { miR-139-5p } \\
\text { miR-181a } \\
\text { miR-181b } \\
\text { miR-193b } \\
\text { miR-361-5p } \\
\text { miR-424 } \\
\text { miR-455 } \\
\text { miR-502-3p } \\
\text { miR-574-3p }\end{array}$} & $\begin{array}{c}\text { Let-7i } \\
\text { miR-21* } \\
\text { miR-146b-5p } \\
\text { miR-182 } \\
\text { miR-663 } \\
\text { miR-1228 }\end{array}$ \\
\hline & & $\begin{array}{l}\text { Acute } \\
\text { rejection }\end{array}$ & $\begin{array}{l}\text { Normal } \\
\text { allograft }\end{array}$ & & & & $\begin{array}{c}\text { miR-150 } \\
\text { miR-155 } \\
\text { miR-663a } \\
\text { miR-638 }\end{array}$ \\
\hline & & DGF & & & & & $\begin{array}{c}\text { miR-17 } \\
\text { miR-18a } \\
\text { miR-20a } \\
\text { miR-21* } \\
\text { miR-106a } \\
\text { miR-106b } \\
\text { miR-182 } \\
\end{array}$ \\
\hline $\begin{array}{l}\text { Maluf [34], } \\
2014\end{array}$ & $\begin{array}{l}\text { Human } \\
\text { deceased } \\
\text { donors }\end{array}$ & IF/TA & $\begin{array}{l}\text { Normal } \\
\text { allograft }\end{array}$ & Urine & Variable & $\begin{array}{c}\text { miR-23b } \\
\text { miR-30a } \\
\text { miR-99a } \\
\text { miR-125b } \\
\text { miR-184 } \\
\text { miR-193b } \\
\text { miR-200b } \\
\text { miR-203 } \\
\text { miR-375 } \\
\text { miR-513a-5p } \\
\text { miR-575 }\end{array}$ & $\begin{array}{c}\text { Let-7f-2 } \\
\text { miR-92a } \\
\text { miR-106b } \\
\text { miR-140a-3p } \\
\text { miR-185 } \\
\text { miR-345 } \\
\text { miR-423-5p } \\
\text { miR-425 } \\
\text { miR-451 } \\
\text { miR-486-5p }\end{array}$ \\
\hline
\end{tabular}

miRNAs in renal IRI and KT. These studies focus on the feasibility of measuring miRNAs and exploring their role in IRI. The clinical studies are characterized by their small sample size. Comparing clinical studies with IRI experiments in small animals is difficult. In animal experiments, IRI is induced by warm ischemia without transplantation. In clinical studies, kidneys underwent substantial cold ischemia, which may influence miRNA expression, and were subjected to alloreactivity in the recipient. Furthermore, animal experiments focus on IRI whilst clinical studies study biomarker potential for rejection or IF/TA.

Hitherto, no specific early biomarker is available for ischemic kidney damage after transplantation. In recent years it has been found that the kinetics of miRNAs in regulating mRNA translation is more complex than previously thought. Regulation succeeds through binding of a miRNA to the mRNA, but feedback loops are also involved as shown in TGF- $\beta 1$ regulation in the kidney [46]. That and the fact that one single miRNA is able to suppress translation of multiple mRNA make it even more difficult to interpret miRNA expression levels alone without studying the effects on target pathways.

miRNAs have the potential to act as specific biomarkers, since it has been shown that miRNAs are dysregulated in disease states as found first in B-cell leukemia [47]. Unfortunately, the different studies revealed different miRNAs as 
TABLE 3: Overview of in vitro experiments. PBMC $=$ peripheral blood mononuclear cells. HREC $=$ human renal epithelial cells. PTEC $=$ proximal tubular epithelial cells. $\mathrm{mTEC}=$ murine tubular epithelial cells.

\begin{tabular}{|c|c|c|c|c|c|c|}
\hline Author & Group & Focus & Control & Time point & MicroRNA- & MicroRNA+ \\
\hline $\begin{array}{l}\text { Muratsu-Ikeda } \\
\text { et al. [44], } \\
2012\end{array}$ & HK-2 cells & $\begin{array}{l}\text { Hypoxia } \\
\text { reoxygenation }\end{array}$ & Sham & $\begin{array}{c}3 \mathrm{~h} \\
10 \mathrm{~h}\end{array}$ & miR-205 & \\
\hline $\begin{array}{l}\text { Aguado-Fraile } \\
\text { et al. [43], } \\
2012 \\
\end{array}$ & $\begin{array}{l}\text { NRK52E cells } \\
\text { HK-2 cells }\end{array}$ & $\begin{array}{l}\text { Hypoxia } \\
\text { reoxygenation }\end{array}$ & Sham & & & miR-127 \\
\hline \multirow[t]{2}{*}{$\begin{array}{l}\text { Anglicheau et al. } \\
{[10], 2009}\end{array}$} & PBMC & \multirow[t]{2}{*}{$\begin{array}{c}\text { PHA } \\
\text { stimulation }\end{array}$} & Sham & & $\begin{array}{l}\text { miR-223 } \\
\text { Let-7c } \\
\text { miR-142-5 }\end{array}$ & \multirow[t]{2}{*}{ miR-155 } \\
\hline & HREC & & Sham & & miR30a-3p & \\
\hline $\begin{array}{l}\text { Godwin et al. [17], } \\
2010\end{array}$ & mTEC & Mineral oil & $\begin{array}{c}\mathrm{miR}-21 \mathrm{KO} \\
\mathrm{miR}-21++\end{array}$ & & & miR-21 \\
\hline $\begin{array}{l}\text { Xu et al. [19], } \\
2012\end{array}$ & HREC & Hypoxia & Normoxia & & & miR-21 \\
\hline $\begin{array}{l}\text { Zell et al. [45], } \\
2014\end{array}$ & PTEC & Hypoxia & Normoxia & & miR-124 & \\
\hline
\end{tabular}

a possible biomarker with no or little overlap between these studies. This may be the result of using different models, biomaterials, or different time points. An ideal biomarker is reproducible, with high specificity and sensitivity. When all reports are taken together, no single miRNA has been reproducibility identified as biomarker. For sensitivity, a reliable assay should be available. This is not yet the case. Even more, the lack of ready-to-use, reproducible assays could bias the results of the studies. When microRNAs found in microarrays are validated with PCR, only those microRNAs which give comparable expression levels are investigated further. This could result in a bias, where only those microRNAs will be examined further, which are validated through PCR. Future studies using RNA sequencing techniques which provide both qualitative and quantitative data could overcome these problems.

Because of their small size and stability, miRNAs could also be used as a therapeutic target by inactivating them using antagomirs or as a therapeutic agent as locked nucleic acids $[48,49]$. Two reports studied differences in miRNA expression between untreated renal IRI and IRI ameliorated by known protective mechanisms, in an attempt to find miRNAs, which are involved in protection against IRI. mir21 was found to be upregulated after IPC, and knockdown diminished the protective effect of IPC [19]. miR-21 thus contributes to the protective effect of IPC on renal IRI. miR-21 was also found to be expressed in tubular epithelial cells [17]. Knockdown resulted in an increased cell death. Nevertheless, overexpression of miR-21 did not result in increased cell survival after oxidative stress. Furthermore, inhibition of miR-21 is only detrimental in combination with IPC. Thus, although miR-21 is obviously involved in protection against IRI, it seems to be part of a more complex mechanism [50]. This mechanism needs to be unravelled to understand the interactions between miRNA-21 and other factors in renal IRI.
Although miRNAs have a great potential as biomarker, therapeutic target, and therapeutic agent in $\mathrm{KT}$, the most important conclusion to be drawn at present is that miRNA research has not led to significant new insights into the pathophysiology of renal IRI, graft rejection, or tolerance and has failed to come up with clinically applicable biomarkers, therapeutic targets, or agents. This could be the result of differences in design of the studies, different tissues used to measure miRNA expression levels, different time points used, and different platforms to determine expression levels of miRNAs. Therefore, studies using more comparable aims, models, patient populations, and expression platforms are needed to determine if miRNAs are able to live up to their expectations in kidney transplantation.

\section{Conflict of Interests}

The authors declare that there is no conflict of interests regarding the publication of this paper.

\section{References}

[1] J. J. Friedewald and H. Rabb, "Inflammatory cells in ischemic acute renal failure," Kidney International, vol. 66, no. 2, pp. 486491, 2004.

[2] N. Perico, D. Cattaneo, M. H. Sayegh, and G. Remuzzi, "Delayed graft function in kidney transplantation," The Lancet, vol. 364, no. 9447, pp. 1814-1827, 2004.

[3] D. P. Bartel, "MicroRNAs: genomics, biogenesis, mechanism, and function," Cell, vol. 116, no. 2, pp. 281-297, 2004.

[4] A. Fire, S. Xu, M. K. Montgomery, S. A. Kostas, S. E. Driver, and C. C. Mello, "Potent and specific genetic interference by doublestranded RNA in caenorhabditis elegans," Nature, vol. 391, no. 6669, pp. 806-811, 1998. 
[5] P. Landgraf, M. Rusu, R. Sheridan et al., "A mammalian microRNA expression atlas based on small RNA library sequencing," Cell, vol. 129, no. 7, pp. 1401-1414, 2007.

[6] Y. Liang, D. Ridzon, L. Wong, and C. Chen, "Characterization of microRNA expression profiles in normal human tissues," $B M C$ Genomics, vol. 8, article 166, 2007.

[7] Y. Sun, S. Koo, N. White et al., "Development of a micro-array to detect human and mouse microRNAs and characterization of expression in human organs," Nucleic Acids Research, vol. 32, no. 22, article el88, 2004.

[8] Z. Tian, A. S. Greene, J. L. Pietrusz, I. R. Matus, and M. Liang, "MicroRNA-target pairs in the rat kidney identified by microRNA microarray, proteomic, and bioinformatic analysis," Genome Research, vol. 18, no. 3, pp. 404-411, 2008.

[9] W. Sui, Y. Dai, Y. Huang, H. Lan, Q. Yan, and H. Huang, "Microarray analysis of MicroRNA expression in acute rejection after renal transplantation," Transplant Immunology, vol. 19, no. 1, pp. 81-85, 2008.

[10] D. Anglicheau, V. K. Sharma, R. Ding et al., "MicroRNA expression profiles predictive of human renal allograft status," Proceedings of the National Academy of Sciences of the United States of America, vol. 106, no. 13, pp. 5330-5335, 2009.

[11] J. M. Lorenzen, I. Volkmann, J. Fiedler et al., "Urinary miR-210 as a mediator of acute $\mathrm{T}$-cell mediated rejection in renal allograft recipients," American Journal of Transplantation, vol. 11, no. 10, pp. 2221-2227, 2011.

[12] I. Z. Ben-Dov, T. Muthukumar, P. Morozov, F. B. Mueller, T. Tuschl, and M. Suthanthiran, "MicroRNA sequence profiles of human kidney allografts with or without tubulointerstitial fibrosis," Transplantation, vol. 94, no. 11, pp. 1086-1094, 2012.

[13] M. J. Scian, D. G. Maluf, K. G. David et al., "MicroRNA profiles in allograft tissues and paired urines associate with chronic allograft dysfunction with IF/TA," American Journal of Transplantation, vol. 11, no. 10, pp. 2110-2122, 2011.

[14] J. Wilflingseder, H. Regele, P. Perco et al., "MiRNA profiling discriminates types of rejection and injury in human renal allografts," Transplantation, vol. 95, no. 6, pp. 835-841, 2013.

[15] R. Danger, A. Pallier, M. Giral et al., "Upregulation of miR-142$3 p$ in peripheral blood mononuclear cells of operationally tolerant patients with a renal transplant," Journal of the American Society of Nephrology, vol. 23, no. 4, pp. 597-606, 2012.

[16] Q. Wei, K. Bhatt, H.-Z. He, Q.-S. Mi, V. H. Haase, and Z. Dong, "Targeted deletion of dicer from proximal tubules protects against renal ischemia-reperfusion injury," Journal of the American Society of Nephrology, vol. 21, no. 5, pp. 756-761, 2010.

[17] J. G. Godwin, X. Ge, K. Stephan, A. Jurisch, S. G. Tullius, and J. Iacomini, "Identification of a microRNA signature of renal ischemia reperfusion injury," Proceedings of the National Academy of Sciences of the United States of America, vol. 107, no. 32, pp. 14339-14344, 2010.

[18] J. Saikumar, D. Hoffmann, T.-M. Kim et al., "Expression, circulation, and excretion profile of microRNA-21, -155, and 18a following acute kidney injury," Toxicological Sciences, vol. 129, no. 2, pp. 256-267, 2012.

[19] X. Xu, A. J. Kriegel, Y. Liu et al., "Delayed ischemic preconditioning contributes to renal protection by upregulation of miR21," Kidney International, vol. 82, no. 11, pp. 1167-1175, 2012.
[20] V. Cantaluppi, S. Gatti, D. Medica et al., "Microvesicles derived from endothelial progenitor cells protect the kidney from ischemia-reperfusion injury by microRNA-dependent reprogramming of resident renal cells," Kidney International, vol. 82, no. 4, pp. 412-427, 2012.

[21] Y. Lee, M. Kim, J. Han et al., "MicroRNA genes are transcribed by RNA polymerase II," The EMBO Journal, vol. 23, no. 20, pp. 4051-4060, 2004.

[22] M. Alvarez-Saavedra, G. Antoun, A. Yanagiya et al., "miRNA132 orchestrates chromatin remodeling and translational control of the circadian clock," Human Molecular Genetics, vol. 20, no. 4, Article ID ddq519, pp. 731-751, 2011.

[23] L. Guo, Y. Liu, Y. Bai, Y. Sun, F. Xiao, and Y. Guo, "Gene expression profiling of drug-resistant small cell lung cancer cells by combining microRNA and cDNA expression analysis," European Journal of Cancer, vol. 46, no. 9, pp. 1692-1702, 2010.

[24] T. Kaucsár, C. Révész, M. Godó et al., "Activation of the miR-17 family and miR-21 during murine kidney ischemia-reperfusion injury," Nucleic Acid Therapeutics, vol. 23, no. 5, pp. 344-354, 2013.

[25] D. J. Hausenloy and D. M. Yellon, "Preconditioning and postconditioning: underlying mechanisms and clinical application," Atherosclerosis, vol. 204, no. 2, pp. 334-341, 2009.

[26] S. V. Narayanan, K. R. Dave, and M. A. Perez-Pinzon, "Ischemic preconditioning and clinical scenarios," Current Opinion in Neurology, vol. 26, no. 1, pp. 1-7, 2013.

[27] N. Selzner, M. Boehnert, and M. Selzner, "Preconditioning, postconditioning, and remote conditioning in solid organ transplantation: basic mechanisms and translational applications," Transplantation Reviews, vol. 26, no. 2, pp. 115-124, 2012.

[28] P. Jia, J. Teng, J. Zou et al., "MiR-21 contributes to xenonconferred amelioration of renal ischemia-reperfusion injury in mice," Anesthesiology, vol. 119, no. 3, pp. 621-630, 2013.

[29] S.-T. Lee, K. Chu, K.-H. Jung et al., "MicroRNAs induced during ischemic preconditioning," Stroke, vol. 41, no. 8, pp. 1646-1651, 2010.

[30] A.-B. Stittrich, C. Haftmann, E. Sgouroudis et al., "The microRNA miR-182 is induced by IL- 2 and promotes clonal expansion of activated helper T lymphocytes," Nature Immunology, vol. 11, no. 11, pp. 1057-1062, 2010.

[31] M. Merkerova, M. Belickova, and H. Bruchova, "Differential expression of microRNAs in hematopoietic cell lineages," European Journal of Haematology, vol. 81, no. 4, pp. 304-310, 2008.

[32] R. Danger, C. Paul, M. Giral et al., "Expression of miR-142-5p in peripheral blood mononuclear cells from renal transplant patients with chronic antibody-mediated rejection," PLoS ONE, vol. 8, no. 4, Article ID e60702, 2013.

[33] A. M. Cheng, M. W. Byrom, J. Shelton, and L. P. Ford, "Antisense inhibition of human miRNAs and indications for an involvement of miRNA in cell growth and apoptosis," Nucleic Acids Research, vol. 33, no. 4, pp. 1290-1297, 2005.

[34] D. G. Maluf, C. I. Dumur, J. L. Suh et al., "The urine microRNA profile may help monitor post-transplant renal graft function," Kidney International, vol. 85, no. 2, pp. 439-449, 2014.

[35] Q. Zhou, S. Haupt, I. Prots et al., "miR-142-3p is involved in $\mathrm{CD} 25^{+} \mathrm{CD} 4 \mathrm{~T}$ cell proliferation by targeting the expression of glycoprotein A repetitions predominant," Journal of Immunology, vol. 190, no. 12, pp. 6579-6588, 2013. 
[36] T. N. MacKenzie, N. Mujumdar, S. Banerjee et al., "Triptolide induces the expression of miR-142-3p: a negative regulator of heat shock protein 70 and pancreatic cancer cell proliferation," Molecular Cancer Therapeutics, vol. 12, no. 7, pp. 1266-1275, 2013.

[37] J. B. Johnnidis, M. H. Harris, R. T. Wheeler et al., "Regulation of progenitor cell proliferation and granulocyte function by microRNA-223," Nature, vol. 451, no. 7182, pp. 1125-1129, 2008.

[38] R. Agrawal, U. Tran, and O. Wessely, “The miR-30 miRNA family regulates Xenopus pronephros development and targets the transcription factor Xlim1/Lhxl," Development, vol. 136, no. 23, pp. 3927-3936, 2009.

[39] J. Li, S. Donath, Y. Li, D. Qin, B. S. Prabhakar, and P. Li, "miR-30 regulates mitochondrial fission through targeting p53 and the dynamin-related protein-1 pathway," PLoS Genetics, vol. 6, no. 1, Article ID e1000795, 2010.

[40] T. Thum, C. Gross, J. Fiedler et al., "MicroRNA-21 contributes to myocardial disease by stimulating MAP kinase signalling in fibroblasts," Nature, vol. 456, no. 7224, pp. 980-984, 2008.

[41] L. B. Frankel, N. R. Christoffersen, A. Jacobsen, M. Lindow, A. Krogh, and A. H. Lund, "Programmed cell death 4 (PDCD4) is an important functional target of the microRNA miR-21 in breast cancer cells," The Journal of Biological Chemistry, vol. 283, no. 2, pp. 1026-1033, 2008.

[42] J. A. Chan, A. M. Krichevsky, and K. S. Kosik, "MicroRNA-21 is an antiapoptotic factor in human glioblastoma cells," Cancer Research, vol. 65, no. 14, pp. 6029-6033, 2005.

[43] E. Aguado-Fraile, E. Ramos, D. Sáenz-Morales et al., "miR127 protects proximal tubule cells against ischemia/reperfusion: identification of kinesin family member 3B as miR-127 target," PLoS ONE, vol. 7, no. 9, Article ID e44305, 2012.

[44] S. Muratsu-Ikeda, M. Nangaku, Y. Ikeda, T. Tanaka, T. Wada, and R. Inagi, "Downregulation of miR-205 modulates cell susceptibility to oxidative and endoplasmic reticulum stresses in renal tubular cells," PLoS ONE, vol. 7, no. 7, Article ID e41462, 2012.

[45] S. Zell, R. Schmitt, S. Witting, H. H. Kreipe, K. Hussein, and J. U. Becker, "Hypoxia induces mesenchymal gene expression in renal tubular epithelial cells: an in vitro model of kidney transplant fibrosis," Nephron Extra, vol. 3, no. 1, pp. 50-58, 2013.

[46] M. Kato, L. Arce, M. Wang, S. Putta, L. Lanting, and R. Natarajan, "A microRNA circuit mediates transforming growth factor-B1 autoregulation in renal glomerular mesangial cells," Kidney International, vol. 80, no. 4, pp. 358-368, 2011.

[47] G. A. Calin, C. D. Dumitru, M. Shimizu et al., "Frequent deletions and down-regulation of micro- RNA genes miR15 and miR16 at 13q14 in chronic lymphocytic leukemia," Proceedings of the National Academy of Sciences of the United States of America, vol. 99, no. 24, pp. 15524-15529, 2002.

[48] J. Elmén, M. Lindow, A. Silahtaroglu et al., "Antagonism of microRNA-122 in mice by systemically administered LNAantimiR leads to up-regulation of a large set of predicted target mRNAs in the liver," Nucleic Acids Research, vol. 36, no. 4, pp. 1153-1162, 2008.

[49] J. Elmén, M. Lindow, S. Schütz et al., "LNA-mediated microRNA silencing in non-human primates," Nature, vol. 452, no. 7189, pp. 896-899, 2008.

[50] T. M. El-Achkar, "Modulation of apoptosis by ischemic preconditioning: an emerging role for miR-21," Kidney International, vol. 82, no. 11, pp. 1149-1151, 2012. 


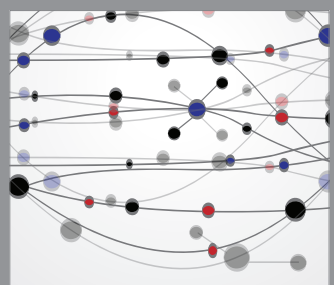

The Scientific World Journal
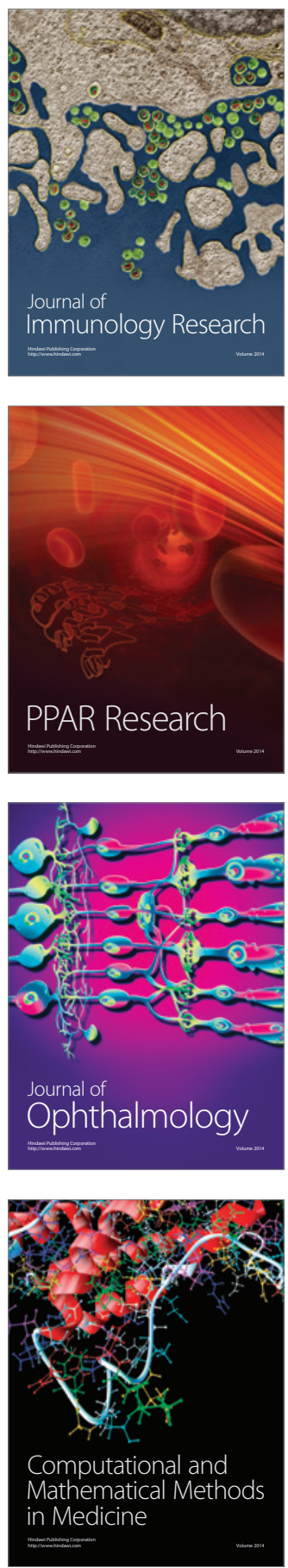

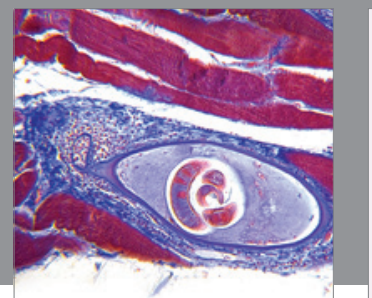

Gastroenterology

Research and Practice
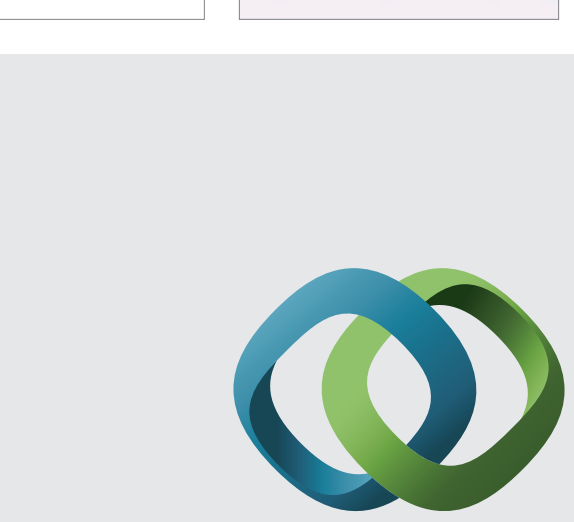

\section{Hindawi}

Submit your manuscripts at

http://www.hindawi.com
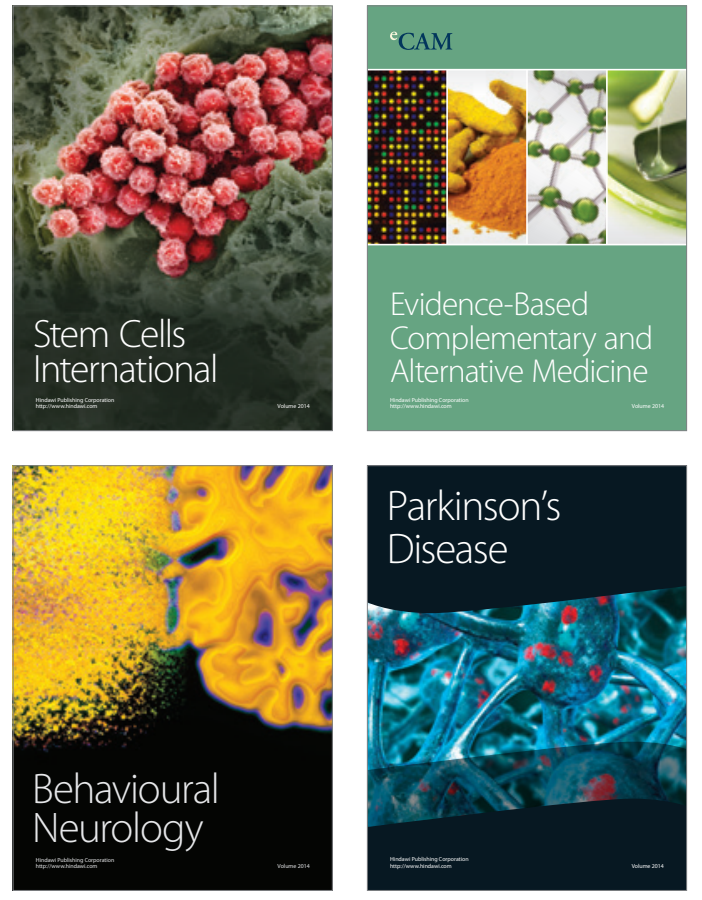
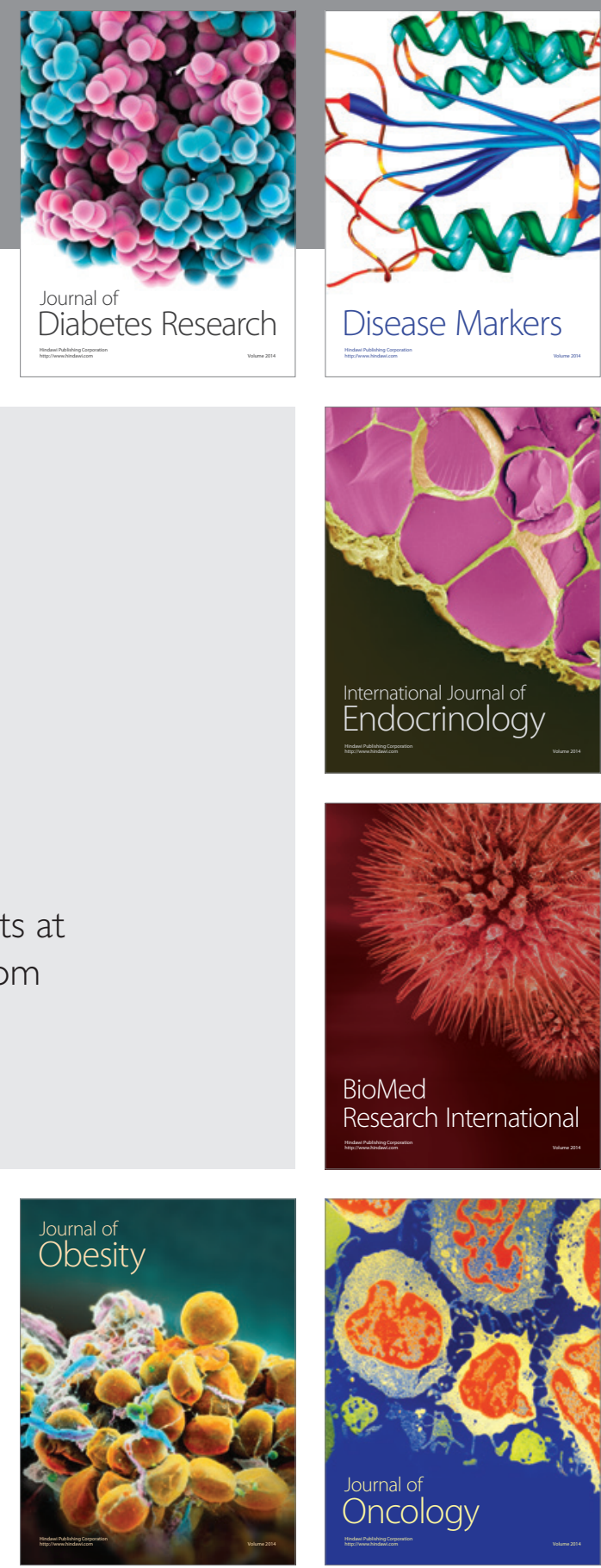

Disease Markers
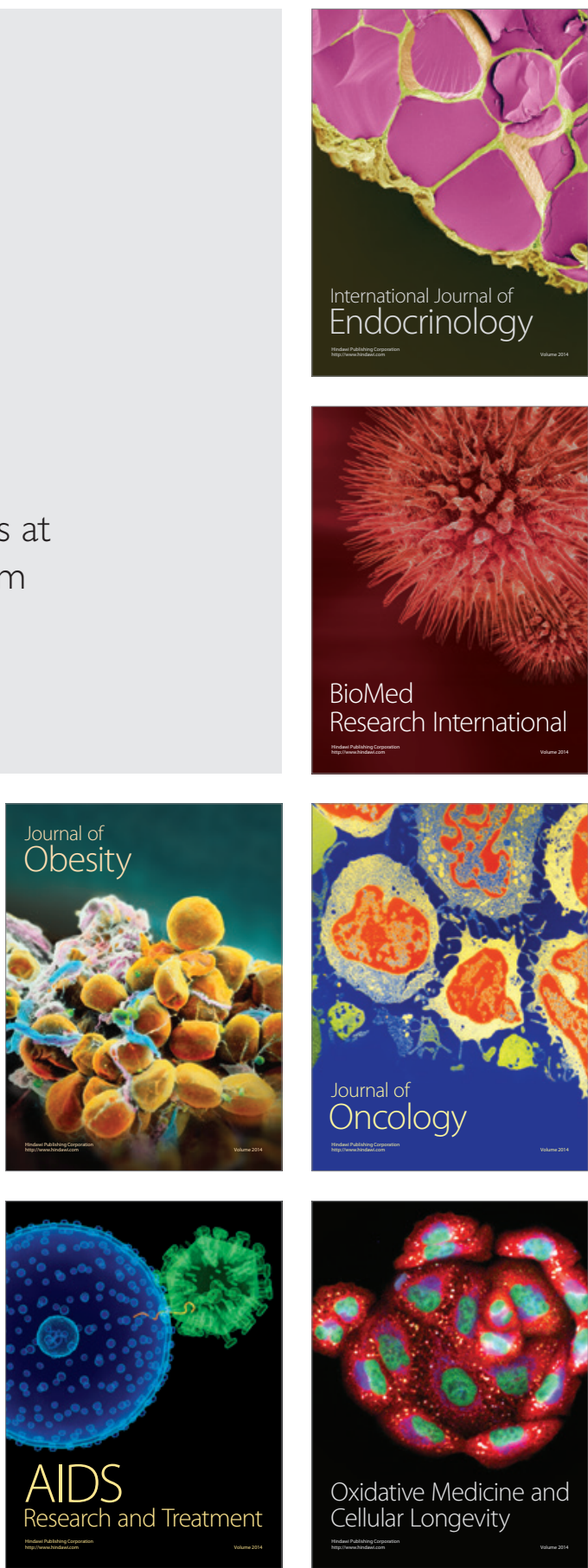